\title{
Only change is constant
}

\section{Three librarians consider what their jobs will be like in five years}

\author{
by Helen H. Spalding, Deborah Abston, and Mark Cain
}

\section{$\mathrm{E}$} d. note: This is the first in a series of columns in which we will invite librarians to comment on aspects of librarianship. This question was posed to each respondent: "It is said the only constant is change. Tell us bow your job responsibilities/functions will be different five years from now." We welcome your responses and will print them as space allou' in "Letters to the Editor."

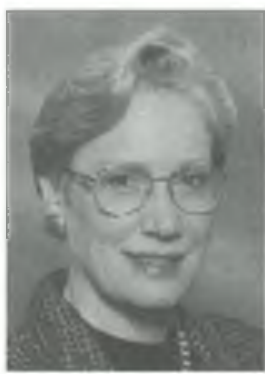

Helen H. Spalding
In addressing changing library service demands and sources of support, administrators need to understand more outside of the library arena to build successful partnerships, recruit and retain outstanding staff, develop quality services, design useful

facilities and computer infrastructures, cultivate new sources of support, and position their libraries for the future.

Partnerships are being formed with new colleagues, such as non-academic libraries, museums, K-12 schools, and corporations. There is increasing interdisciplinary collaboration on campus and among universities. Initiating and negotiating these partnerships call upon new skills to work successfully with dissimilar cultures, communication styles, perceptions, priorities, and values in new relationships. Innovative means of insuring equitable contribution. mutual benefit, and accountability will be conceived, requiring unique agreements, contracts, and fee arrangements without precedent.

Collaboration also may lead to greater strength in the markets where we procure the collections, systems, services, and databases.

In the past, it was easier to define our students and faculty and the dividing line between that primary client group and others. We will be developing policies and procedures for providing services to students and faculty at a distance who may be affiliated with other institutions at the same time, and to the general community whose public libraries are sharing databases of collections and patrons with academic libraries. This diverse user group will require accommodation for wide differences in cultural and educational background, in physical and learning abilities, and in service expectations. Our gifts, grants, and contracts sources also are changing, and an increasing amount of administrators' time will be spent in marketing new service initiatives to funding sources, and in fund and friend raising.

Larger numbers of our workforce are requiring more leave time or temporary,

\section{About the authors}

Helen H. Spalding is associate director oflibraries at the University of Missouri-Kansas City, e-mail: spaldingh@umkc. edu; Deborah Abston is a reference librarian at ArizonaState University Libraries, e-mail:dabston@mainex 1.asu edu; Mark Cain is executivedirector of InformationSenvices \& Supportat the CollegeofMountSt.Joseph, email:mark_cain@mail.msj.edu 
part-time alternatives to address the health needs of themselves or their parents. The recruitment and retention of qualified employees are requiring administrators to design greater flexibility in the workplace. Candidates are not just looking for a job, but for a lifestyle. We will be exploring ways to support the increasing investment needed in staff training and designing new positions requiring specific skills and credentials atypical for traditional libraries, such as digital engineers, educational technologists, pedagogy specialists, and graphic designers.

If new resources are not developed at the pace of new service needs being generated, reallocation of traditional services and functions will have to be made. Library administrators must make difficult choices at a risktaking pace and survive the political landmines inherent in such change. But they also have the opportunity to provide leadership for their campuses in making the dramatic changes required of them because of similar transformations in their resource base and market.-Helen H. Spalding

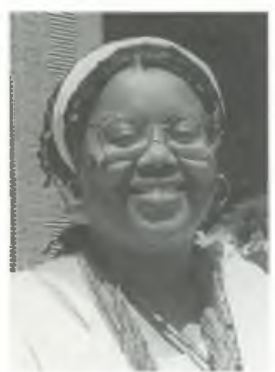

Deborah Abston
While in library school several years ago, I had an assignment to write a paper on what I thought the library world would be like in 25 years. Even though I am a fan of science fiction and think of myself as somewhat imaginative, my future library was rather bland. Mind you, this was before the explosion of the Internet and the Web.

What will my job be like in five years? What comes to mind is more of the same. Advents in the world of technology will affect our jobs in the same ways they do now. Our jobs will be more complex due to more and larger databases of information. Interactions with library users will last longer due to their bewilderment at the vast arrays of information sources available for their use. We will be scrambling to learning how to use these databases and stay one step ahead of our users.
I know that some think less instruction will be required and that the how-to's on using these information sources are evident, but in my experience that is not the case, so we will be doing more instruction than ever-both in-person and in classes. To some of you, that probably sounds exactly like your job today.

Even though I feel there will be just as much patron interaction, I also think I will be more isolated from my peers and library users in some ways. Technology has already affected the ways in which we communicate; even telephone usage is down for me. I sometimes don't even see my colleagues for a few days at a time, even though we are at work everyday.

I will know more about computer technology than I do at the present time, there will certainly be a lot more to know. I am on my third computer in eight years, in five years I will be on my fifth or sixth.

In five years, my job will be somewhat depressing, exciting, frustrating, and fulfilling, just like it is now. I will feel dumber and smarter, pretty much like I feel now.Deborab Abston

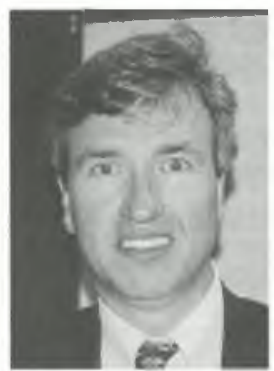

Mark Cain
I am chief information officer of a small, liberal arts college, with responsibility for the library, instructional and administrative computing, networking, institutional research, and strategic planning.

As a manager, I will continue to plan, manage the budget, super-

vise staff, and do a certain amount of politicking. Yet because of the rapid changes in technology and the increasingly competitive higher education market, some things will be different.

Strategic planning in all parts of my operation will be a constant activity, but the planning timeframe will be shorter - two to three years instead of five. It may even begin to look tactical instead of strategic.

Distance learning will become more prominent, and I will have to devote more time to supporting the development of entire academic programs online. This will have an effect on the library, and we will need to plan 
for electronic reserves systems, home clelivery of monographic and other "hard-copy" materials, and remote (probably Web-based) library use instruction.

We will be installing wireless networking in the library and elsewhere on my campus. With more and more students, faculty, and staff using laptops instead of speciallyconfigured and hard-wired public PCs, we will need a common interface. That interface will likely remain the Web. We will spend less time configuring machines and more time designing user interfaces/front ends.

There will be less focus on the acquisition and servicing of technology-whether that technology is in the library, on a faculty/staff member's desktop, or in a computer lab. More important will be fostering the effective use of that technology to improve research, learning, and service; to streamline administrative processes; to reduce costs; and to increase revenue. A great deal of attention will be given to process reengineering. In the library, this will mean reconceiving library technical processes and helping users redesign tried-and-true but now obsolescent research methodologies.
Finally, I expect to spend a greater portion of my time on the values of higher education, discussing all, protecting some, discarding others. (I see this as an extension of the important dialogue ACRL began last year.) Progressively more confused by our fast-changing world, we in higher education will check this headlong progress against our ethical bedrock, asking some important questions along the way. "Who are we? What do we stand for? What are we trying to accomplish?"

In planning services and systems, it will be in part my responsibility to ensure that new services and systems take advantage of technological advances without betraying our core values.-Mark Cain

\section{Your opinion is sought}

CERL Neus wants opinions from librarians, faculty, and administrators in all types of academic institutions, holding a variety of positions. To be considered as a respondent to a question-based "Way I See It" column, please send your name, title, institution, e-mail address, and photo to "Way I See It," CERL Neus, ACRL/ALA, 50 E. Huron St., Chicago IL 606112795.
(Crimea '98 continued from p. 596)

\section{An IFLA update}

Leo Voogt provided plenary attendees with an overview of recent developments within IFLA, characterizing them as indicative of a strong period of growth and serious investment in information technology. He pointed out that one of IFLA's cornerstones has been, and remains, the volunteer effort of many experts and specialists from around the world.

While he applauded the growth and development of information technology within the context of IFIA's activities, he made a point of stating that "efforts must be fed by electronic communication, but cannot flourish without personal communication."

For this to occur, he argued for a strong need for IFLA to continue to rely on personal networks, networks that can be established and maintained curing IFLA's general conference, and, he added, during important regional events like the Crimea conference.

\section{The global perspective}

Phyllis Spies, vice president, Sales and In- ternational OCLC, presented "OCLC and Member Libraries: Architects of the Global Library." Using a PowerPoint presentation, Spies described the viewpoints of various persons from different countries throughout the world.

Her presentation explored two points: one, the key trends in the global information marketplace and, two, a brief characterization of OCLC's strategic international directions in light of these global trends. She spoke about the information revolution, comparing and contrasting it to the industrial revolution, pointing out that "technology's effects on us today are different from those of the industrial revolution. They are more democratic, more personal; more subtle and profound."

Crimed '98 was indeed an interesting and rewarding experience. It has become the dominant conference throughout central and Eastern Europe and annually provides an excellent forum and context for large numbers of librarians throughout the region to intermingle, to network, to exchange views and experiences, and to profit from one another: 